\title{
Burnout Levels of Handball Players with Respect to Age, Gender and Experience
}

\author{
Turhan TOROS \\ 'School of Physical Education and Sports, Coaching Education Department Mersin University, Turkey \\ Email:turhantoros@yahoo.com
}

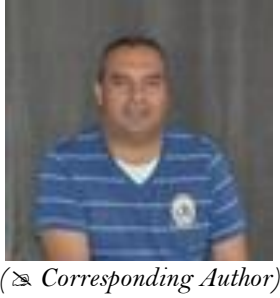

Corresponding Author)

\begin{abstract}
The aim of this study was to investigate burnout levels of handball players in terms of age, gender and experience. In this study, 116 female and 128 male, totally 244 handball players with the mean age $22.39 \pm 1.98$ year participated voluntarily. Maslach Burnout Inventory that originally developed by Maslach and Jackson (1981) and adapted to Turkish population by Ergin (1992) was used for measuring the burnout levels of handball players. The data of this research analyzed with SPSS package program and to test the internal consistency of the scale, Cronbach Alpha coefficient was calculated. According to the binary group comparisons, it was determined that the data were not normally distributed and therefore Mann Whitney $U$ test was used. And also, The Kruskall Wallis $\mathrm{H}$ test was used for the multiple group comparisons. According to Mann Whitney $\mathrm{U}$ test results, there were no significant differences in emotional burnout ( $\mathrm{p}=.088, \mathrm{p}>.05)$, depersonalization $(\mathrm{p}=.411, \mathrm{p}>.05)$ and personal accomplishment $(\mathrm{p}=.503, \mathrm{p}>.05)$ between male and female handball players. According to Kruskall Wallis $\mathrm{H}$ test results, there were no significant differences in emotional burnout $(\mathrm{p}=.152 ; \mathrm{p}>.05)$, depersonalization $(\mathrm{p}=.310 ; \mathrm{p}>.05)$ and personal accomplishment $(\mathrm{p}=.301, \mathrm{p}>.05)$ sub dimensions according to age and no significant difference was found in the subscale of personal accomplishment $(\mathrm{p}=.641 ; \mathrm{p}>.05)$ according to the experience variable. But, there were statistically significant difference in emotional burnout $(\mathrm{p}=.003 ; \mathrm{p}<.05)$ and depersonalization $(\mathrm{p}=.008 ; \mathrm{p}<.05)$ sub - dimensions according to experience variable. As a result, burnout level and depersonalization are thought to be important in terms of the experience of handball players.
\end{abstract}

Keywords: Burnout, Emotional burnout, Depersonalization, Personal accomplishment.

Citation | Turhan TOROS (2018). Burnout Levels of Handball Players with Respect to Age, Gender and Experience. Asian Journal of Education and Training, 4(1): 29-34.

\section{History:}

Received: 4 December 2017

Revised: 28 December 2017

Accepted: 9 January 2018

Published: 25 January 2018

Licensed: This work is licensed under a Creative Commons

Attribution 3.0 License (c)) E E

Publisher:Asian Online Journal Publishing Group
Funding: This study received no specific financial support.

Competing Interests: The author declares that there are no conflicts of interests regarding the publication of this paper.

Transparency: The author confirms that the manuscript is an honest, Transparency: The author confirms that the manuscript is an honest,
accurate, and transparent account of the study was reported; that no vital features of the study have been omitted; and that any discrepancies from the study as planned have been explained.

Ethical: This study follows all ethical practices during writing.

\section{Contents}

1. Introduction

2. Method

31

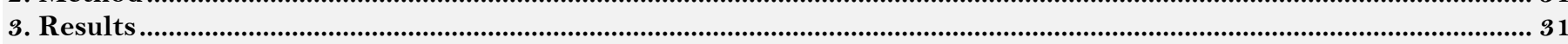

4. Discussion............................................ 39

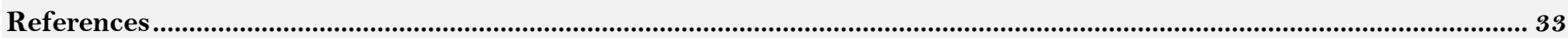




\section{Introduction}

Fundamentally, human instincts are the emotions that connect human beings to life and enable them to sustain their generation in the face of the repression of nature. The concept of stress at the top of these feelings is a form of motivation, which is a solution to many basic problems such as escape from the hunter, protection of the child, fighting hunger, protecting the hierarchy in the social environment. The higher ranks of working life that emerged with the liberal economic transition of society and the expectation from the working life holds the individual under a certain stress, and thus stress, which is a source of motivation in the beginning, can be depressed if it is not controlled over time, and therefore burnout syndrome appears psychologically and clinically. Stress has a long history in the field of psychiatry and has been a subject of research for many years due to its distinctive and significant effects on individual behavior and performance. In fact, stress can make it hard to perform general body functions that one can easily do under normal conditions (John and Mason, 1975). Today, stress has been an integral part of human life and found great importance in order to determine personal health or disorder (Sherman, 1996). If the stress in the sport environment is long lasting, it can turn into burnout. Burnout has been defined to occur as a consequence of chronic stress that causes a young athlete to cease participation in a previously enjoyable activity (Difiori et al., 2014). Burnout is considered as a situation that should be avoided because of bringing heavy and serious consequences for the individual (Sermon, 1994). The concept of burnout has begun to be considered by researchers as a research topic since the 1970s (Budak and Sürvegil, 2005). Burnout is a syndrome that leads to physical, emotional and mental fatigue, often experienced by individuals working in occupations serving people (Byrne, 1999). Freudenberger (1975) refers only to the dimension of emotional exhaustion and defines burnout as "a state of exhaustion resulting from failure, wear, energy and loss of power, or demands that cannot be met on human internal resources". Burnout syndrome also refers to physical and mental exhaustion due to lack of motivation (Sürgevil, 2005). Many researchers were united in the idea that burnout includes exhaustion, expectations, attitudes, and perceptions, which are the inner psychological experiences that emerge at a personal level (Raedeke, 1997; Pines and Aranson, 1998; Raedeke and Smith, 2009). According to this new concept of "burnout", whatever work is done, it shows that there are an ups and downs between what people do and what they have to do; and in addition represents worthiness, dignity, respectability, the erosion of individuals' soul. In other words, it is stated that the compulsive effects of activity on the person lead to energy loss and exhaustion over time. From a psychological point of view, specific intentional orientations, such as participating in training or performing mandatory activities or examinations, can be defined as "work" and equally meaning "work" (Lemyre et al., 2007). In sport, the concept of burnout is a long-term abandonment of the individual's activities, and during this period the athlete does not feel excited to practice and match and also evaluates himself as unsuccessful and inadequate. In time, moving away from sports also removes it from social life. According to Pines and Aranson (1998) the main reason for individual's exhaustion is the training environment, which keeps the athlete under constant emotional pressure. In this context, the type of oppression, the content and the scope are a major influence. Burnout according to Maslach; is defined as a three-dimensional syndrome that manifests itself in emotional exhaustion, depersonalization, and lack of personal sense of accomplishment in people (Maslach, 2003). The emotional exhaustion experienced by the athlete here, especially with the intense workout tempo, causes the athlete to under intense stress (Shelley et al., 2014).

Subsequently, Maslach and Jackson (1981) concluded that burnout; physical and mental dimension syndrome involving physical fatigue, long fatigue, helplessness and hopelessness in the human body, as well as negative attitudes towards the work, the life and other people that the individual has made. According to Maslach, the most important dimension of burnout is emotional exhaustion. Many researchers have pointed out that the dimension of emotional exhaustion, which can be observed most clearly by burnout, needs to be examined more than the other two dimensions (Maslach and Jackson, 1981). The depersonalization dimension, which forms the second dimension of the burnout syndrome, is a cold behavior and apathy. People are behaving like they are objects to people they meet (Maslach, 2003). On the other hand personal success means that one evaluates him as inadequate and unsuccessful at work (Wright and Bonett, 1997). At this dimension, the person feels that he cannot be successful personally, he begins to believe that nobody likes him and develops feelings of inadequacy in communicating with his colleagues (Maslach, 2003). Learning the causes of burnout can be effective in regulating the results. The causes of burnout can be handled in two groups as personal and organizational (Budak and Sürvegil, 2005). Factors such as age, marital status, over-commitment to work, personal expectations, performance, stress in personal life, job satisfaction, support from individuals and informed relatives are examined under the heading of personal reasons. The nature of work, type of workplace, duration of work, characteristics of workplace, workload, job tension, role uncertainty, educational status, disagreement, intra organizational relations, economic and social factors can be considered as the organizational causes of burnout. With the business conditions in recent years; personality traits, the manner in which one looks at stressful situations, and the ways of coping with them suggest that individual levels of extinction show even when similar stresses are encountered (Masum et al., 2016). When the athletes are unable to cope with these demands, negative adjustments are to be expected, such as loss of motivation and burnout, which may lead to decreased performance and sport dropout (Gautheur et al., 2016). Some previous research findings have emphasized that the social environments importance of the in the development of athlete burnout (Gould et al., 1996; Raedeke and Smith, 2001; Gustafsson et al., 2011; Quested and Duda, 2011) and some researches suggested that motivational disposition of athletes influences by the quality of the coach athlete relationship (Adie and Jowett, 2010; Riley and Smith, 2011). In addition the associations between basic needs satisfaction and burnout or the relationships between behavioral regulations and burnout has been research topics. (Cresswell and Eklund, 2005; Lemyre et al., 2006; Perreault et al., 2007; Hodge et al., 2008).

Coaches and sport psychologists' understanding the antecedents of athletes' burnout so effective interventions are momentous. Examining the differences of athlete burnout is therefore an important task for researchers aiming to better understand burnout and its occurrence. As with all other sports, it is clear that the psychological well being of the athletes will have a positive impact on performance in handball. In the light of this information the burnout have become important to handball players. At the same time, the question of what might be the cause of sportsmen's burnout has emerged. Accordingly, the aim of this study was to examine the burnout levels of handball 
players with respect to gender, age and experience.

\section{Method}

\subsection{Participants}

In this study; 116 female and 128 male totally 244 (Mean age, $x=22.39 \pm 1.98$ year) handball player participated voluntarily. The participants gave their informed constant for the experimental procedure as required by the Helsinki declaration. As this research was a questionnaire-based study with handball players there was no requirement in Turkey to seek ethics committee approval.

\subsection{Measures}

Maslach Burnout Inventory that originally developed by Maslach and Jackson (1981) and adapted to Turkish population by Ergin (1992) was used for the data collection. This scale consists of three subdivisions. The Maslach Burnout Inventory has 22 items on a five-point rating scale and three subscales: Emotional Burnout (9 items), Depersonalization (5 items) and Personal Accomplishment (8 items). Each item in the scale is a 7-point Likert-type measure that allows marking from o to 6 . Emotional burnout subdivision describes feelings of being exhausted by the job (score range 0-36). Depersonalization subdivision deals with self-esteem and behavior towards recipients of care, which lacks emotion for the individual (score range 0-20). Personal accomplishment subdivision addresses feelings about ability to cope with the problems of working directly with people in the work environment (score range 0-32). When Emotional Burnout and Depersonalization scores are high and Personal Accomplishment score is low; that means considered indicating burnout (Maslach and Jackson, 1981).

The reliability of the scale was examined by two methods by Ergin (1992). Firstly internal consistency is calculated and an internal consistency coefficient of the data is as follows: Emotional Burnout .83, Depersonalization .65 and Personal Accomplishment .72. Reliability was also examined by test-retest method as 24 weeks after the first application researchers were reached 99 participants. Test-retest reliability coefficients for the subdivisions of the scale were: Emotional Burnout .83, Depersonalization .72 and Personal Accomplishment .67. As a result of the reliability analysis conducted for this research, emotional burnout $\alpha=0.75$, depersonalization $\alpha=0.54$, personal accomplishment $\alpha=0.72$ and total burnout $\alpha=0.81$. The construct validity of the Maslach Burnout Inventory was examined by examining the factor structure. Factor analysis first revealed 5 natural factors and it was seen that they were aggregated in 3 factors. It has been reevaluated with varimax rotation, as recommended by Maslach and Jackson (1981) and also as practiced by other researchers. As a result, three basic factors as emotional burnout, depersonalization and personal accomplishment have emerged (Ergin, 1992). As a result of the analysis of the internal consistency coefficient reconstructed in our research, the alpha coefficients are as follows: Emotional Burnout .82, Depersonalization .75, Personal Accomplishment 83.

\subsection{Data Collection}

The research was made with volunteer handball players who agreed to participate in the survey and before the training the researchers applied the scale. Necessary information has been given to the participants on the purpose of the study and the protection of confidentiality.

\subsection{Data Analysis}

When the data were analyzed with the help of the SPSS package program, the Cronbach's alpha coefficient was calculated to test the internal consistency of the scale. Firstly, test of normality was performed in data analysis. Since the number of sample is greater than 50, the Kolmogorov-Smirnov Normality Test is considered. The Kolmogorov-Smirnov Normality Test didn't show normal distribution because the resultant significance value was smaller than 0.05. Thus, Mann Whitney U test was used for the binary group comparisons, as it was determined that the data did not exhibit a normal distribution. The Kruskall Wallis H test was used for the multiple group comparisons.

\section{Results}

Examination of the burnout levels of the handball players in terms of gender variation is shown in Table 1.

Table-1. Analysis of Different Burnout Levels of Handball Players According to Gender Variance (Mann Whitney U Test)

\begin{tabular}{|c|c|c|c|c|c|c|}
\hline & Gender & $\mathbf{n}$ & Rank Average & $\mathbf{U}$ & $\mathbf{Z}$ & $\mathbf{p}$ \\
\hline \multirow{3}{*}{ Emotional Burn-out } & Male & 128 & 124.44 & \multirow{3}{*}{7356.5} & \multirow{3}{*}{-1.758} & \multirow{3}{*}{.088} \\
\hline & Female & 116 & 117.40 & & & \\
\hline & Total & 244 & & & & \\
\hline \multirow{3}{*}{ Depersonalization } & Male & 128 & 113.36 & \multirow{3}{*}{8003.5} & \multirow{3}{*}{-.634} & \multirow{3}{*}{.411} \\
\hline & Female & 116 & 127.87 & & & \\
\hline & Total & 244 & & & & \\
\hline \multirow{3}{*}{ Personal Accomplishment } & Male & 128 & 118.22 & \multirow{3}{*}{8151.5} & \multirow{3}{*}{-.441} & \multirow{3}{*}{.503} \\
\hline & Female & 116 & 129.16 & & & \\
\hline & Total & 244 & & & & \\
\hline
\end{tabular}

According to the results of Mann Whitney $\mathrm{U}$ test, no significant difference was found between male and female handball players in the variables of emotional burnout $(\mathrm{p}=.088, \mathrm{p}>.05)$, Depersonalization $(\mathrm{p}=.411, \mathrm{p}>.05)$ and Personal Accomplishment ( $\mathrm{p}=.503, \mathrm{p}>$.05) (Table 1$)$.

Examination of burnout levels of handball players in terms of age variable is shown in Table 2. 
Table-2. Analysis of Different Burnout Levels of Handball Players According to Age Variance (Kruskall Wallis H Test)

\begin{tabular}{|c|c|c|c|c|c|}
\hline & Age & $\mathbf{n}$ & Rank Average & $x^{2}$ & p \\
\hline \multirow{4}{*}{ Emotional Burn-out } & $20-22$ age & 140 & 124.52 & \multirow{4}{*}{3.777} & \multirow{4}{*}{.152} \\
\hline & 23-25 age & 83 & 112.26 & & \\
\hline & $26+$ age & 21 & 111.83 & & \\
\hline & Total & 244 & & & \\
\hline \multirow{4}{*}{ Depersonalization } & 20-22 age & 140 & 126.02 & \multirow{4}{*}{2.239} & \multirow{4}{*}{.310} \\
\hline & 23-25 age & 83 & 131.39 & & \\
\hline & $26+$ age & 21 & 155.71 & & \\
\hline & Total & 244 & & & \\
\hline \multirow{4}{*}{ Personal Accomplishment } & 20-22 age & 140 & 134.01 & \multirow{4}{*}{2.418} & \multirow{4}{*}{.301} \\
\hline & 23-25 age & 83 & 127.55 & & \\
\hline & $26+$ age & 21 & 154.53 & & \\
\hline & Total & 244 & & & \\
\hline
\end{tabular}

When the research findings were examined in Table 2, according to the Kruskall Wallis $\mathrm{H}$ test no significant difference was found in terms of age variable for the Emotional Burnout $(p=.152, p>.05)$, Depersonalization $(\mathrm{p}=.310, \mathrm{p}>.05)$ and Personal Accomplishment $(\mathrm{p}=.301, \mathrm{p}>.05)$ subdivisions results (Table 2$)$.

Examination of the burnout level of handball players in terms of experience change is shown in Table 3.

Table-3. Analysis of Different Burnout Levels of Handball Players According to Experience Variable (Kruskall Wallis H Test)

\begin{tabular}{|c|c|c|c|c|c|}
\hline & Experience & $\mathbf{n}$ & Rank Average & $x^{2}$ & $\mathbf{p}$ \\
\hline \multirow{4}{*}{ Emotional Burn-out } & $1-4$ year & 140 & 129.11 & \multirow{4}{*}{11.544} & \multirow{4}{*}{$.003^{*}$} \\
\hline & $5-8$ year & 76 & 81.67 & & \\
\hline & $9+$ year & 28 & 113.83 & & \\
\hline & Total & 244 & & & \\
\hline \multirow{4}{*}{ Depersonalization } & $1-5$ year & 140 & 123.19 & \multirow{4}{*}{5.841} & \multirow{4}{*}{$.008^{*}$} \\
\hline & 6-10 year & 76 & 87.79 & & \\
\hline & $11+$ year & 28 & 130.71 & & \\
\hline & Total & 244 & & & \\
\hline \multirow{4}{*}{ Personal Accomplishment } & $1-5$ year & 140 & 125.52 & \multirow{4}{*}{.581} & \multirow{4}{*}{.641} \\
\hline & 6-10 year & 76 & 110.79 & & \\
\hline & $11+$ year & 28 & 120.19 & & \\
\hline & Total & 244 & & & \\
\hline
\end{tabular}

When the research findings were examined in Table 3, according to the Kruskall Wallis $\mathrm{H}$ test results, no significant difference was found in terms of experience variable for Personal Accomplishment $(\mathrm{p}=.641, \mathrm{p}>.05)$ subdivision. But, significant differences were found in the subdivisions of Emotional Burnout $(\mathrm{p}=.003, \mathrm{p}<.05)$ and Depersonalization $(\mathrm{p}=.008, \mathrm{p}<.05)$ according to the experience variable.

\section{Discussion}

The aim of this study was to investigate burnout levels of handball players in terms of age, gender and experience. Psychological symptoms are less pronounced than other symptoms that can be seen in people who experience burnout. These indications are; feelings of frustration and nervousness, feelings of extreme emotional distress and uneasiness, impatience, self-reliance, enmity towards the environment, weakness, energy loss, desperation about the work, criticizing other people, indifference, increase in family problems, dissatisfaction, negative attitudes towards others, decline in positive emotions such as courtesy, respect and friendship, uncertainty and complexity in thinking, unsubstantiated doubts, depression, feeling of guilt and helplessness. Other signs of burnout are thinking about quitting job and reluctant to work (Ardıç and Polatci, 2008). When the research findings were examined, according to Mann Whitney U test results, there was no significant difference between male and female handball players according to gender variables in Emotional Burnout, Depersonalization and Personal Accomplishment subdivisions and also no significant difference was found in Kruskall Wallis $\mathrm{H}$ test results according to age variable in these three subdivisions. Similar to our study, Sermon (1994) examined the relationship between age, gender and duration of work and burnout levels of secondary school teachers. There was no relationship between demographic variables such as age, gender, and years of work and burnout in the results of the study. When the approach model is examined, it can be said that the reason for not making a meaningful difference according to the gender variable may be derived from the basic dynamics, and it is theoretically possible to explain that the sampled area is caused by the variability. In agreement with these results, it is in line with Goodger et al. (2007) and Gould et al. (1996) which states that males experience more burnout. Conversely, Gustafsson et al. (2007) showed consistency with the finding that male students had more depersonalization than female students despite the fact that female students had more burnout than male students. Consistent with our study some studies reported no difference between the burnout scores of employees according to gender variable (Cresswell and Eklund, 2005; Cresswell and Eklund, 2006). Very few studies applied to student groups make it difficult to make assessments and show that both genders may encounter burnout problems as in working groups. This study is compatible with the literature.

According to Ünal et al. (2001) burnout is seen at a higher rate in early ages and this is due to the inexperience and inadequacy of the individual. As the age of the individual progresses and the experience increases, the prevalence of burnout decreases. In terms of sports psychology, when the topic is evaluated, it is necessary to continue today, individual effort and premium etc. the fact that there is no salary and assignment according to the procedure suggests that age-related burnout syndrome is not affected in sports. 
Surveys conducted by university students in other countries show that the level of burnout is negatively related to school loyalty. Furthermore academic stress, relationships with teachers and friends, academic selfefficacy and academic achievement is predicted burnout (Schaufeli et al., 2002; Zhang et al., 2005). Breso et al. (2007) conducted intercultural survey and found that there was no significant difference in the level of burnout by gender but found that girls had a higher level of burnout and loss of belief.

Burnout generally increases with age. Kutsal and Bilge (2012) stated that the level of loss of emotional burnout and belief in $12^{\text {th }}$ grade students is higher than that of $9^{\text {th }}, 10^{\text {th }}$ and $11^{\text {th }}$ grade students. Stoeber et al. (2011) examined the relationship between passionate and willing work and academic achievement and burnout in university students. According to research findings, passionate and willing work constitute significant differences in burnout levels and academic achievement depending on the individual differences among the students. In our study according to the Kruskall Wallis $\mathrm{H}$ test results, no significant difference was found in terms of experience variable for Personal Accomplishment subdivision. But, significant differences were found in the subdivisions of Emotional Burnout and Depersonalization according to the experience variable.

Exhaustionists are psychologically withdrawn. Psychological withdrawal is seen in the form of entering into superficial relationships, spending time deliberately misplaced in persons, distracting, or moving away from the recipient. The consequences of withdrawal are:1) Low performance, 2) Escape from duty, 3) Hiding behind rules (Maslach and Jackson, 1981).

According to the findings of our study, the relationship between the concepts of burnout and experience of handball players is consistent with the general literature. The relationship between the concepts of burnout and experience of handball players is consistent with the general literature. This means that the athlete who has gained experience over time does not feel pressure and stress from the training and competition over time.

When studies of burnout in handball players are examined, it can be seen that different measurement methods are used. Yavari et al. (2013) conducted a study to find out the relation between burnout and motivation in professional handball players, which were handball prime league male players of twelve teams. They used Athletic Burnout Questionnaire and Sport Motivation Scale. The findings of the study was showed that there was a positive and significant relation between total burnout with motivation, extrinsic motives and motiveless. But there wasn't a significant relation between burnout and intrinsic motives. Also there was a significant relation between burnout subscales (reduced sense of accomplishment, emotional. physical exhaustion, devaluation) with motivation and motiveless (Yavari et al., 2013). Furthermore; Guillet and Gautheur (2008) examined the links between goal orientation and burnout in handball players. The results showed that the ego- and task-oriented adolescents are more self-determined, are less anxious, are more self-confident, and perceive a more important achievement in comparison to other groups of athletes (Guillet and Gautheur, 2008).

In this study, the differentiation between burnout and experience concepts is consistent with the general literature. According to Tümkaya (1999) generally burnout is a basic concept that emerged in the first and last years of a job. In terms of sports, the reason of this can be interpreted that the phases starting with excitement in the first years of sports and resulting in excessive training reach the degree of weariness and anxiety over time in the individual. As a result, the experience of handball players is important in terms of burnout level. Investigations to be conducted in the following years may include a survey covering all branches. In addition to burnout syndrome, it is recommended to investigate other negativities experienced by the athletes.

\section{References}

Adie, J.W. and S. Jowett, 2010. Meta-perceptions of the coach-athlete relationship, achievement goals, and intrinsic motivation among sport participants. Journal of Applied Social Psychology, 4O(11): 2750-2773. View at Google Scholar | View at Publisher

Ardıç, K. and S. Polatci, 2008. Emotional exhaustion: An application to academic personal (the Case of Gazi Osman Pasa Univer sity). İktisadi ve İdari Bilimler Fakültesi Dergisi, 10(2): 1-28. View at Google Scholar

Breso, E., M. Salanova and W.B. Schaufeli, 2007. In search third dimension of burnout: Efficacy or inefficacy? Applied Psychology: An International Review, 56(3): 460-478. View at Google Scholar | View at Publisher

Budak, G. and O. Sürvegil, 2005. An application on the academic staff on the analysis of organizational factors affecting burnout and burnout. Dokuz Eylül University Faculty of Economics and Administrative Sciences. Magazine, 20(2): 95-108. View at Google Scholar

Byrne, B.M., 1999. The nomological network of teacher burnout: A literature review and empirically validated model. In R. Vandenberghe \& A. M. Huberman (Eds.), Understanding and Preventing Teacher Burnout: A Sourcebook of International Research and Practice. pp: $15-37$

Cresswell, S.L. and R.C. Eklund, 2005. Changes in athlete burnout and motivation over a 12-week league tournament. Medicine and Science in Sports and Exercise, 37(11): 1957-1966. View at Google Scholar | View at Publisher

Cresswell, S.L. and R.C. Eklund, 2006. Athlete burnout: Conceptual confusion, current research and future research directions. In S. Hanton \& S. D. Mellalieu (Eds.), Literature reviews in sport psychology. New York: Nova Science Publishers.

Difiori, J.P., H.J. Benjamin, J.S. Brenner, A. Gregory, N. Jayanthi, G. Landry and A. Luke, 2014. Overuse injuries and burnout in youth sports: A position statement from the American medical society for sports medicine. British Journal of Sports Medicine, 48(4): 287288. View at Google Scholar | View at Publisher

Ergin, C., 1992. Adaptation of burnout and maslach burnout scale in doctors and nurses. VII. Scientific Studies of the National Psychology Congress, September 22-25. Ankara: Turkish Psychological Association Publications. pp: 143-154.

Freudenberger, H.J., 1975. The staff burn-out syndrome in alternative institutions. Psychotherapy: Theory, Research \& Practice, 12(1): 7382. View at Google Scholar $\mid$ View at Publisher

Gautheur, S.I., E.G. Descas and H. Gustafsson, 2016. Athlete burnout and the risk of dropout among young elite handball players. Sport Psychologist, 30(2): 123-130. View at Google Scholar $\mid$ View at Publisher

Goodger, K., T. Gorely, D. Lavallee and C. Harwood, 2007. Burnout in sport: A systematic review. Sport Psychologist, 21(2): 127-151. View at Google Scholar | View at Publisher

Gould, D., S. Tuffey, E. Udry and J. Loehr, 1996. Burnout in competitive junior tennis players: II. Qualitative analysis. Sport Psychologist, 1O(4): 341-366. View at Google Scholar | View at Publisher

Guillet, E. and S. Gautheur, 2008. Links between motivational orientation and burnout: A study in adolescent handballers at high level. Science et Sports, 23(1): 35-37. View at Google Scholar

Gustafsson, H., G. Kentta and P. Hassmen, 2011. Athlete burnout: An integrated model and future research directions. International Review of Sport and Exercise Psychology, 4(1): 3-24. View at Google Scholar | View at Publisher

Gustafsson, H., G. Kenttä, P. Hassmén and C. Lundqvist, 2007. Prevalence of burnout in competitive adolescent athletes. Sport Psychologist, 21(1): 21-37. View at Google Scholar $\mid$ View at Publisher

Hodge, K., C. Lonsdale and J.Y.Y. Ng, 2008. Burnout in elite rugby: Relationships with basic psychological needs fulfillment. Journal of Sports Sciences, 26(8): 835-844. View at Google Scholar | View at Publisher

John, W. and M.D. Mason, 1975. A historical view of the stress field. Journal of Human Stress, 1(2): 22-36. View at Google Scholar $\mid$ View at Publisher 
Kutsal, D. and F. Bilge, 2012. A study on the burnout and social support levels of high school students. Education and Science, $37(164): 283-$ 297. View at Google Scholar

Lemyre, N.P., T. D.C. and G.C. Roberts, 2006. Influence of variability in motivation and affect on elite athlete burnout susceptibility. Journal of Sport and Exercise Psychology, 28(1): 32-48. View at Google Scholar | View at Publisher

Lemyre, P.N., G.C. Roberts and J. Stray-Gundersen, 2007. Motivation, overtraining, and burnout: Can self-determined motivation predict overtraining and burnout in elite athletes? European Journal of Sport Science, 7(2): 115-126. View at Google Scholar $\mid$ View at Publisher

Maslach, C., 2003. Burnout: The cost of caring. Malor Books, Cambridge MA. pp: 106-107.

Maslach, C. and S.E. Jackson, 1981. MBI: Maslach burnout inventory. Palo Alto, CA, 1(2): 49-78. View at Google Scholar

Masum, A.K.M., A.K. Azad, K.E. Hoque, L.S. Beh, P. Wanke and Ö. Arslan, 2016. Job satisfaction and intention to quit: An empirical analysis of nurses in Turkey. Peer Journal, 4: e1896. View at Google Scholar $\mid$ View at Publisher

Perreault, S., P. Gaudreau, M.C. Lapointe and C. Lacroix, 2007. Does it take three to tango? Psychological need satisfaction and athlete burnout. International Journal of Sport Psychology, 38(4): 437-450. View at Google Scholar

Pines, A. and E. Aranson, 1998. Career burnout, causes and cures. New York: The Free Press.

Quested, E. and J.L. Duda, 2011. Antecedents of burnout among elite dancers: A longitudinal test of basic needs theory. Psychology of Sport \& Exercise, 12(2): 159-167. View at Google Scholar $\mid$ View at Publisher

Raedeke, T.D., 1997. Is athlete burnout more than just stress? A sport commitment perspective. Journal of Sport \& Exercise Psychology, 19(4): 396-417. View at Google Scholar | View at Publisher

Raedeke, T.D. and A.L. Smith, 2001. Development and preliminary validation of an athlete burnout measure. Journal of Sport \& Exercise Psychology, 23(4): 281-306. View at Google Scholar | View at Publisher

Raedeke, T.D. and A.L. Smith, 2009. The athlete burnout questionnaire manual. Morgantown, WV: Fitness Information Technology. West Virginia University.

Riley, A. and A.L. Smith, 2011. Perceived coach-athlete and peer relationships of young athletes and self-determined motivation for sport. International Journal of Sport Psychology, 42(1): 115-133. View at Google Scholar

Schaufeli, W.B., I. Martinez, A. Marques-Pinto, M. Salanova and A. Bakker, 2002. Burnout and engagement in university students: A crossnational study. Journal of Cross Cultural Studies, 33(5): 464-481. View at Google Scholar $\mid$ View at Publisher

Sermon, J.M., 1994. The relationship of the dual role assignment to the level of perceived burnout by secondary teachers. Dissertation Abstracts International, $55(9): 2765$.

Shelley, L., M. Christopher, E. Brooke, F. Steven and F. Steven, 2014. Athlete Burnout: Is the type of a sport factor?. Sport Journal, 55(19): 1-4. View at Google Scholar

Sherman, M.A., 1996. Investigate of young sport coach behavior. Journal of Sport Management, 10(2): 27-35.

Stoeber, J., H. Julian, A. Jennifer and R. Alexandra, 2011. Passion and motivation for studying: Predicting academic engagement and burnout in university students, UK. Educational Psychology, 31 1(4): 513-528. View at Google Scholar |View at Publisher

Sürgevil, O., 2005. Çalışma hayatında tükenmişlik sendromu: Tükenmişlikle mücadele teknikleri. Ankara: Nobel Yayın.

Tümkaya, S., 1999. Burnout levels and coping behaviours of teachers. Türk Psikolojik Danışma ve Rehberlik Dergisi, 2(2): 26-36.

Ünal, S., R. Karlıdağ and S. Yoloğlu, 2001. Relationships between burnout, job satisfaction and life satisfaction in physicians. Klinik Psikiyatri, 4(2): 113-118. View at Google Scholar

Wright, T.A. and R. Bonett, 1997. The contribution of burnout to work performance. Journal of Organizational Behavior, 18(5): 491-499. View at Google Scholar | View at Publisher

Yavari, Y., M.R. Ismaeli and J. Rezaie, 2013. Relation between burnout and motivation among elite handball players. International Journal of Sport Studies, 3(9): 1015-1022. View at Google Scholar

Zhang, Y., Y. Gan and H. Cham, 2005. The reliability and validity of MBI-SS and academic characteristics affecting burnout. Chinese Journal of Clinical Psychology, 13(4): 383-385. View at Google Scholar 